\title{
Mobbing in the Case of Primary Health Care Providers
}

Oya Dirican ${ }^{1 *}$, Özge Abacı Bozyel ${ }^{1}$, Dilek Öztaş ${ }^{2}$

${ }^{1}$ Antalya Provincial Health Directorate, Antalya -TURKEY

${ }^{2}$ Ankara Yıldırım Beyazıt Üniversitesi Tıp Fakültesi Halk Sağlığı Anabilim Dalı

*Corresponding Author: Oya Dirican, M.D.Antalya Provincial Health Directorate, Korkuteli District Health Directorate Uzunoluk Mahallesi, 447. Sk. No:16, 07800 Korkuteli/Antalya

\section{Received date: November 19, 2021; Accepted date: December 27, 2021; Published date: January 05, 2022}

Citation: Oya Dirican, Özge Abacı Bozyel, Dilek Öztaş (2022). Mobbing in the Case of Primary health Care Providers. J. Archives of Medical Case Reports and Case Study, 5(1); DOI:10.31579/2692-9392/098

Copyright: (c) 2022 Oya Dirican, This is an open access article distributed under the Creative Commons Attribution License, which permits unrestricted use, distribution, and reproduction in any medium, provided the original work is properly cited.

\section{Abstract}

Objectives: Primary healthcare workers are the main drivers of the population-oriented health education programs. In this work, we aim to offer an account of the conditions that lead to mobbing in Primary Health Care Employees, and of the ways to address this problem and its consequences.

Methods: This study has been conducted on the medical staff in primary health care units in the province of Antalya, with the permission of the Provincial Health Directorate and the approval of the ethics board of the Antalya Education and Research Hospital. It was planned as a cross-sectional study; survey forms were filled out by 752 employees during an internal training for primary health care in 2017. After informing the subjects regarding the aims of the study, we gave them a survey of 21 questions. The average time for the individuals to answer the questions was 30 minutes. The survey was designed to ask the individuals their age, gender, educational background and occupation, whether they know of any case of mobbing, whether they were subjected to mobbing themselves and for how long, the position and the gender of the perpetrator, and whether and how they addressed the issue. The answers of the participants were analyzed with descriptive statistical analysis, the frequencies were determined and chi-square test was used.

Results: $72.2 \%$ (543) of the participants declare that they heard the words "mobbing" or "psychological harassment" before. In our study, the rate of exposure to mobbing was found to be $30.4 \%$ among primary care providers. We have found that mobbing exposure was significantly higher among females and midwives and nurses. Our study reveals that in every occupational group perpetrators are mostly in management positions; that 36-45 age group was the most victimized group by both genders; that the most common method in order to handle mobbing is the loss of communication which is a new problem between the perpetrator and the victim and that the most common response to mobbing is to share it with friends; and our study finds that the period of mobbing in the midwife-nurse group is mostly 19 months and more, while this period takes to 9-12 months in the case of doctors.

Discussion: One of the most important steps in preventing mobbing is to take timely measures in organizations and to prevent the problem from harming the organization and employees. Educating employees about emotional assault within their working environment is proposed as an important solution for them to protect themselves when they are subjected to harassment.

Key words: mobbing; primary health care employees; harrasment in workplace

\section{INTRODUCTION}

Mobbing is a set of systematically sustained, malicious attitudes and actions carried out in the workplace by one or more individuals, intending to intimidate and pacify certain other co-workers or force them to quit and damaging their personal values, professional status, social relations and health. [1-13]
Mobbing is a public health issue, with its increasingly frequent occurrence having direct and indirect social costs such as loss of labor and increase in the use of medication and leave among its victims, and should be addressed as such. 
The purpose of mobbing is thought to be to force individuals to quit their jobs by putting systematic pressure on them that would undermine their work performance and stamina. [13-16]

The parties to mobbing are victims, perpetrators, and by-standers. [17,18] The victim experiences difficulty in defining the problem they are going through and identifying its causes mostly because of the slow onset of the process of psychological violence they are subjected to. The victim's behavior is mocked and insulted, and their communication with co-workers is intercepted for a long period of time (minimum six months) and periodically (minimum once a week). However, the victim struggles to stand firm against these hostile actions and feels helpless. They fail to defend themselves against the accusations directed at them because of various reasons such as the personality of the individual, the lack of job security, and the powerful status of the perpetrators within the organization. This defenseless state of the victim furthers the psychological violence and its effects. The effects of the psychological violence on the status of the victim in the workplace and their mental and physical health thus escalate. [19] Mobbing can be committed by peers or even subordinates as well as senior management. It is argued that those who are engaged in mobbing have excessively controlling, cowardly, neurotic, and power hungry personalities and their behaviors stem from insecurity, fear and jealousy. $[3,7,8,13,18,20,21]$

Mobbing has a negative impact on the general productivity, interpersonal relations and peace within the workplace. It causes disharmony between management and employees, increases absenteeism and medical leaves, undermines loyalty to the organization, leads to the loss of competent and experienced employees, increases the employee turnout, and damages the reputation of the institution when it is publicized.

The economic burden of mobbing is also significant. It leads to an increase in the medical expenses of the victims and loss of productivity in the workplace due to time spent for their medical control and treatment. Thus, mobbing harms the victim's relationship with the society and places a burden on the employer and the government. According to the October 2000 report of the International Labor Organization (ILO), in Germany absences due to psychological health problems cost $\$ 2.2$ million every year.[3]

Today, mobbing is a leading cause of poor performance and failure in private and public organizations in the world and in Turkey today.[22,23] It is widely accepted that some form of mobbing is present in the workplace all around the world.[24]

Primary healthcare workers are the main drivers of the population-oriented health education programs. They have to be equipped with accurate and adequate information to be able to serve as trainer and consultant in the preventive healthcare services not only against physical welness but also psychological wellness. It is important to raise consciousness about this issue in order to find an effective solution for it through new studies. In this work, we aim to offer an account of the conditions that lead to mobbing in Primary Health Care Employees, and of the ways to address this problem and its consequences.

\section{Materials and Methods}

This study has been conducted on the medical staff in primary health care units in the province of Antalya, with the permission of the Provincial Health Directorate and the approval of the ethics board of the Antalya Education and Research Hospital. It was planned as a cross-sectional study; survey forms were filled out by 752 employees during an internal training for primary health providers in 2017. This internal training is planned all of employees in primary care providers including doctors, nurses-midwives, medical secretaries, environmental health technicians, laboratory technicians, X-ray technicians, data manager, health officers from Provincial Directorate (PC), Public Health Center (PHC), Family Health Center (FHC) and Public Health Laboratory (PHL). Sixty-four employees (7.8\%) who did not participate in training were not included in the study. Non-participants were had same distribution with participants according to job and workplace, and their reason about not participating to the internal training was that they had a training about mobbing already. After informing the subjects regarding the aims of the study, we gave them a survey of 21 questions. A questionnaire was prepared to determine the knowledge attitude and behaviors of primary health care workers about exposure to mobbing and what to do if necessary. The survey was designed to ask the individuals their age, gender, educational background and occupation, whether they know of any case of mobbing, whether they were subjected to mobbing themselves and for how long, the position and the gender of the perpetrator, and whether and how they addressed the issue. Also, they were asked not to write their names because they had to be kept confidential. The average time for the individuals to answer the questions was 30 minutes. A total of 752 individuals participated in the study. The answers of the participants were analyzed with descriptive statistical analysis, the frequencies were determined and chi-square test was used. The obtained data were presented with descriptive tables.

\section{Results}

The average age of 752 primary health care workers that participate in the study is $39.8 \pm 7.7$ (minimum 18 and maximum 64 ). $70.3 \%$ of them are women (529 participants) and $29.7 \%$ men (223 participants). 110 participants (14.6\%) are employed in the PD, 388 (51.6\%) in the PHC, 232 $(30.2 \%)$ in the FHC and $22(2.9 \%)$ in PHL. $2.3 \%$ (17 participants) are primary school graduates, $2.7 \%$ (20 participants) secondary school graduates, $14.8 \%$ (111 participants) high school graduates, $31.3 \%$ (235 participants) technical college graduates, $41.6 \%$ (313 participants) university graduates and $7.4 \%$ (56 participants) hold masters or doctorate degrees. $20.7 \%$ (156) of the participants are doctors, $46.2 \%$ (348) of them are nursemidwives (241 midwives and 107 nurses), the remaining 33\% are Environmental Health Technicians, Laboratory technicians, X-ray technicians, data managers, health officers. $72.2 \%$ (543) of the participants declare that they heard the words "mobbing" or "psychological harassment" before.

When the participants are provided with the definition of "mobbing" or "bullying" and asked if they have been subjected to it, 30 of them did not respond, $16.8 \%$ (126) responded that they were subjected to mobbing, $13.6 \%$ (102) responded that they have been partially subjected to mobbing and $65.7 \%$ (494) of them responded that they have not been subjected to any form of mobbing.

$35.3 \%$ (184) of women responded that they have been fully or partially subjected to mobbing; $84.1 \%$ (126) of those who have been fully subjected to mobbing and $76.4 \%$ (102) of those who have been partially subjected to mobbing are female employees. This difference is statistically significant $\left(\chi^{2}\right.$ $=19.08, p=0.0001)($ Table 1$)$. 


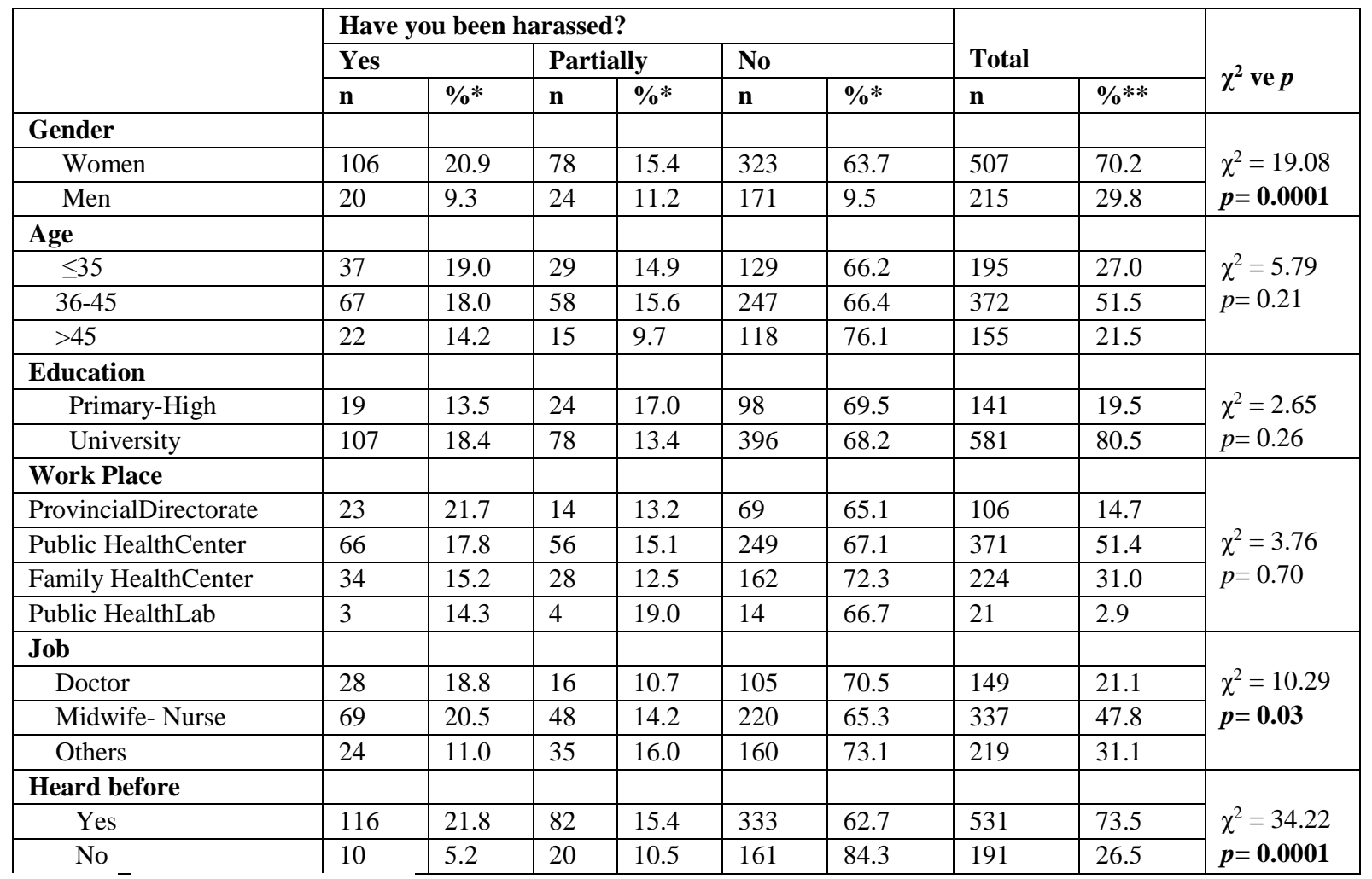

* The percentage row. $* *$ The percentage column

Table 1: Characteristics of Participants

While age, level of education and place of duty do not appear to be factors statistically associated to the exposure to mobbing, $52.3 \%$ of those who report to have been subjected to are PHC employees, $84.9 \%$ of them are university graduates and $53.2 \%$ of them are between $36-45$ years of age, and $54.9 \%$ of those who reported to have been partially subjected to mobbing are PHC employees, $76.4 \%$ of them are university graduates and $56.8 \%$ of them are between 36-45 years of age.

When the relationship between occupation and exposure to mobbing is considered, we observe that the midwife-nurse group is the largest among those who report to have been fully $(54.8 \%)$ and partially $(47.1 \%)$ bullied. This is statistically significant $\left(\chi^{2}=10.29, p=0.03\right)$. It was found that those who had previously heard of the word "mobbing" report more frequently that they have been subjected to mobbing $(\chi 2=34.22, p=0.0001)$ (Table 1). $35.9 \%$ of those who think that they have been subjected to mobbing have not done anything to solve the problem; $45.2 \%$ state that they have preferred to talk with their friends about the problem, $30.7 \%$ state that they have reported it to SABIM / BIMER (Government Communication Centers) and $21.4 \%$ to their supervisor. $16.7 \%$ of them have demanded to be assigned to another unit or institution, $8.3 \%$ of them have reported the problem to their union and $5.7 \%$ of them have filed a lawsuit. The least observed reactions are calling 170 (Labor and Social Security Call Center), seeking advice from a counselor, reciprocating the physical and/or psychological assaults of the perpetrators and contacting labor associations against mobbing (Table 2).

\begin{tabular}{|l|l|l|}
\hline Response Behaviors & n & \% $^{*}$ \\
\hline I shared mobbing with my friends & 103 & 45.2 \\
\hline I did not do anything & 82 & 35.9 \\
\hline I reported to CIMER ** & 70 & 30.7 \\
\hline I reported in the institution / organization & 49 & 21.4 \\
\hline I requested to be appointed to another place/ institution & 38 & 16.7 \\
\hline I reported to trade unions & 19 & 8.3 \\
\hline I filed a lawsuit & 13 & 5.7 \\
\hline I received support from a counselor & 9 & 3.4 \\
\hline I called 170 & 3 & 1.3 \\
\hline I resigned & 3 & 1.3 \\
\hline I responded to perpetrators with physical and/or psychological assault & 3 & 1.3 \\
\hline I contacted to labor associations against mobbing & 1 & 0.4 \\
\hline
\end{tabular}

*Since some victims have taken more than one type of action. the percentage is more than 100 percent. 
**Presidency's Communication Center (CIMER), which operates under Presidency's Directorate of Communications make resolution of the questions and problems of every citizen.

Table 2: Response Behaviors of Victims

$72.7 \%$ (136) of the victims were married during the mobbing practice, $88.8 \%$ (151) were employed in the institution for 5 years and less, $49.1 \%$ of the perpetrators (81) were supervisors, and $53.8 \%$ (122) of them were male. $25.5 \%$ (46) of the victim had more than one perpetrators, and the mobbing lasted generally 19 months and more. 38.2\% (87) of the victim stopped communicating with the perpetrators as a result of mobbing. Predominantly seen among those who have at least a high school education, the midwifenurse occupational group, 36-45 age group, and PHC employees (Table 3).

\begin{tabular}{|c|c|c|c|c|c|c|}
\hline & \multicolumn{2}{|c|}{$\begin{array}{l}\text { I did not do anything }+ \text { I } \\
\text { shared mobbing with my } \\
\text { friends }\end{array}$} & \multicolumn{2}{|c|}{$\begin{array}{l}\text { I complained in the } \\
\text { institution / organization }\end{array}$} & \multicolumn{2}{|c|}{$\begin{array}{l}\text { Requested to be appointed to } \\
\text { another place / institution }\end{array}$} \\
\hline & $\mathbf{n}$ & $\%$ & $\mathbf{n}$ & $\%$ & $\bar{n}$ & $\%$ \\
\hline \multicolumn{7}{|l|}{ Job } \\
\hline Doctor & 15 & 75.0 & 4 & 20.0 & 1 & 5.0 \\
\hline Midwife-Nurse & 48 & 51.6 & 11 & 11.8 & 34 & 36.6 \\
\hline Others & 23 & 69.7 & 4 & 12.1 & 6 & 18.2 \\
\hline \multicolumn{7}{|l|}{ Age } \\
\hline$<36$ & 26 & 74.3 & 8 & 22.9 & 1 & 2.8 \\
\hline $36-45$ & 48 & 72.7 & 7 & 10.6 & 11 & 16.7 \\
\hline$>45$ & 15 & 75.0 & 3 & 15.0 & 2 & 10.0 \\
\hline \multicolumn{7}{|l|}{ Education } \\
\hline Primary-High School & 17 & 70.8 & 3 & 12.5 & 4 & 16.7 \\
\hline University & 72 & 74.2 & 15 & 15.5 & 10 & 10.3 \\
\hline \multicolumn{7}{|l|}{ Work place } \\
\hline ProvincialDirectorate & 16 & 80.0 & 2 & 10.0 & 2 & 10.0 \\
\hline Public HealthCenter & 46 & 69.6 & 12 & 18.2 & 8 & 12.2 \\
\hline Family HealthCenter & 22 & 78.6 & 4 & 14.3 & 2 & 7.1 \\
\hline Public HealthLab & 5 & 71.4 & 0 & 0.0 & 2 & 28.6 \\
\hline
\end{tabular}

Table 3. Reactions to Mobbing Categorized According to the Characteristics of Victims

As far as the perpetrators of mobbing are concerned, superiors constitute the largest group, but the victims under the age of 36 have been mostly harrassed by their subordinates. Multiple exposures to mobbing are more common among doctors, and the university graduates and the employees of the PHC and FHC are more often subjected to mobbing by their subordinates. There are more men than women among perpetrators. However, in the midwifenurse group, more of the perpetrators are women. The most victimized group in both genders is the 36-45 age group. Male perpetrators harrass mosty university graduates and female perpetrators harrass high school and lower level school graduates (Table 4).

Table 4: Status and Gender of Perpetrators According to Characteristics of Victims

\begin{tabular}{|c|c|c|c|c|c|c|c|c|c|c|c|c|c|c|c|c|}
\hline & \multicolumn{10}{|c|}{ Status of perpetrators } & \multicolumn{6}{|c|}{ Gender of perpetrators } \\
\hline & \multicolumn{2}{|c|}{$\begin{array}{l}\text { Managers } \\
\text { /Superiors }\end{array}$} & \multicolumn{2}{|c|}{ Peers } & \multicolumn{2}{|c|}{$\begin{array}{l}\text { Managers and } \\
\text { Peers }\end{array}$} & \multicolumn{2}{|c|}{$\begin{array}{l}\text { Subordin } \\
\text { ates }\end{array}$} & \multicolumn{2}{|c|}{$\begin{array}{l}\text { Managers } \\
\text { peers and } \\
\text { subordinates }\end{array}$} & \multicolumn{2}{|c|}{ Women } & \multicolumn{2}{|c|}{ Men } & \multicolumn{2}{|c|}{$\begin{array}{l}\text { Male- } \\
\text { Female } \\
\text { Multiple } \\
\text { perpetrators }\end{array}$} \\
\hline & $\mathbf{n}$ & $\%$ & $\mathbf{n}$ & $\%$ & $\mathbf{n}$ & $\%$ & $\mathbf{n}$ & $\%$ & $\mathbf{n}$ & $\%$ & $\mathbf{n}$ & $\%$ & $\mathbf{n}$ & $\%$ & $\mathbf{n}$ & $\%$ \\
\hline \multicolumn{17}{|l|}{ Job } \\
\hline Doctor & 17 & 51.5 & 7 & 21.2 & 6 & 18.2 & 1 & 3.0 & 2 & 6.1 & 6 & 16.6 & 20 & 55.6 & 10 & 27.8 \\
\hline Midwife- Nurse & 48 & 51.6 & 26 & 27.9 & 16 & 17.2 & 2 & 2.2 & 1 & 1.1 & 41 & 41.8 & 30 & 30.6 & 27 & 27.4 \\
\hline Others & 15 & 39.6 & 13 & 34.2 & 8 & 21.2 & 1 & 2.5 & 1 & 2.5 & 11 & 26.2 & 23 & 54.8 & 8 & 19.0 \\
\hline \multicolumn{17}{|l|}{ Age } \\
\hline$<36$ & 27 & 51.9 & 16 & 30.8 & 7 & 13.5 & 2 & 3.8 & 0 & 0.0 & 22 & 39.3 & 26 & 46.4 & 8 & 14.3 \\
\hline $36-45$ & 38 & 42.7 & 26 & 29.2 & 21 & 23.6 & 1 & 1.1 & 3 & 3.4 & 32 & 33.3 & 37 & 38.5 & 27 & 28.2 \\
\hline$>45$ & 16 & 57.1 & 6 & 21.4 & 4 & 14.3 & 1 & 3.6 & 1 & 3.6 & 5 & 17.3 & 13 & 44.8 & 11 & 37.9 \\
\hline
\end{tabular}




\begin{tabular}{|c|c|c|c|c|c|c|c|c|c|c|c|c|c|c|c|c|}
\hline \multicolumn{17}{|l|}{ Education } \\
\hline $\begin{array}{l}\text { Primary-High } \\
\text { School }\end{array}$ & 9 & 39.1 & 6 & 26.1 & 7 & 30.4 & 0 & 0.0 & 1 & 4.4 & 9 & 33.3 & 7 & 26.0 & 11 & 40.7 \\
\hline University & 72 & 49.3 & 42 & 28.8 & 25 & 17.1 & 4 & 2.7 & 3 & 2.1 & 50 & 32.5 & 69 & 44.8 & 35 & 22.7 \\
\hline \multicolumn{17}{|l|}{ Work place } \\
\hline Provincial Directorate & 12 & 46.2 & 7 & 26.9 & 7 & 26.9 & 0 & 0.0 & 0 & 0.0 & 10 & 37.0 & 13 & 48.1 & 4 & 14.9 \\
\hline Public Health Center & 44 & 45.4 & 30 & 30.9 & 19 & 19.5 & 2 & 2.1 & 2 & 2.1 & 31 & 30.7 & 42 & 41.6 & 28 & 27.7 \\
\hline Family Health Center & 22 & 53.7 & 10 & 24.4 & 6 & 14.6 & 2 & 4.9 & 1 & 2.4 & 14 & 29.2 & 21 & 43.8 & 13 & 27.0 \\
\hline Public Health Lab & 3 & 60.0 & 1 & 20.0 & 0 & 0.0 & 0 & 0.0 & 1 & 20.0 & 4 & 80.0 & 0 & 0.0 & 1 & 20.0 \\
\hline
\end{tabular}

In the midwife-nurse group mobbing lasts mostly longer than 18 months. But this period shortens to 6-11 months in the case of doctors. Employees under 36 years of age are usually subjected to mobbing for more than 1 year. The most victimized group in both educational level is the 19 months and more group (Table 5).

Table 5. Period of Exposure According to Characteristics of Victims

\begin{tabular}{|c|c|c|c|c|c|c|}
\hline & \multicolumn{2}{|c|}{ 6-11 Months } & \multicolumn{2}{|c|}{ 12-18 Months } & \multicolumn{2}{|c|}{19 months and more } \\
\hline & $\mathbf{n}$ & $\%$ & $\mathbf{n}$ & $\%$ & $\mathbf{n}$ & $\%$ \\
\hline \multicolumn{7}{|l|}{ Job } \\
\hline Doctor & 13 & 56.5 & 6 & 26.1 & 4 & 17.4 \\
\hline Midwife- Nurse & 11 & 22.0 & 18 & 36.0 & 21 & 42.0 \\
\hline Others & 6 & 26.1 & 3 & 13.0 & 14 & 60.9 \\
\hline \multicolumn{7}{|l|}{ Age } \\
\hline$<36$ & 5 & 19.2 & 9 & 34.6 & 12 & 46.2 \\
\hline $36-45$ & 21 & 36.8 & 15 & 26.3 & 21 & 36.8 \\
\hline$>45$ & 4 & 23.5 & 4 & 23.5 & 9 & 52.9 \\
\hline \multicolumn{7}{|l|}{ Education } \\
\hline Primary-High & 3 & 17.6 & 3 & 17.6 & 11 & 64.7 \\
\hline University & 27 & 32.5 & 25 & 30.1 & 31 & 37.3 \\
\hline \multicolumn{7}{|l|}{ Work place } \\
\hline ProvincialDirectorate & 6 & 31.6 & 7 & 36.8 & 6 & 31.6 \\
\hline Public HealthCenter & 14 & 26.9 & 10 & 19.2 & 28 & 53.8 \\
\hline Family HealthCenter & 10 & 40.0 & 10 & 40.0 & 5 & 20.0 \\
\hline Public HealthLab & 0 & 0.0 & 1 & 25.0 & 1 & 25.0 \\
\hline
\end{tabular}

\section{Discussion}

The problem of mobbing (psychological violence in workplace), which can result in quitting if not solved, is frequently encountered in recent years. For this reason, studies on mobbing are expanding.[24]

In our study, the rate of exposure to mobbing was found to be $30.4 \%$ among primary care providers. Other studies show that 18 to $37 \%$ of health professionals are exposed to mobbing.[16,25] Considering these results, we can say that we have found a similar result.

We have found that mobbing exposure was significantly higher among females and midwives and nurses, which is also consistent with other studies on this subject.[26,27] In contrast to these results, two studies show that male employees are more exposed to intimidation than female employees.[28,29] However, there is also a study showing that gender does not make a difference in exposure.[30]

Studies show that health care professionals are more than 16 times more likely to suffer from mobbing than other service sector workers, and show that nurses are at three times more risk among other health workers.[13,31,32] Among the health care professionals, psychological violence is more common in nursing than in other occupations.[13,15,33-39] While a statistically significant relationship between the exposure to mobbing and the level of education is not observed, the literature suggests that employees with higher education suffer from mobbing more.[11,40] Our study reveals that in every occupational group perpetrators are mostly in management positions. Other studies also show similar results. This suggests that managers do not work towards the personnel satisfaction. One study finds that the rate of nurses exposed to mobbing by managers is $36.7 \%$. In the literature research, $81 \%$ of the employees stated that they were exposed to mobbing by their managers and $58 \%$ by their peers. In a study conducted by ANF (Australian Nursing Federation) in Australia with registered nurses (442 individuals), nurses first identified their managers and supervisors, then their peers, patients and employers as responsible for mobbing.[40]

Our study finds that 36-45 age group was the most victimized group by both genders. Mobbing victims are mostly 41-50 years old people, but in our country people between 25-30 years of age are reported to suffer intense 
mobbing.[13,41,42] A study on mobbing practices and work stress finds that those in the 20-35 age group are exposed to more mobbing.[43]

Studies do not reveal a statistically significant relationship between nurses' average years of experience and their exposure to mobbing. This is consistent with our findings. Similarly when the mobbing exposure status of the nurses who participated in the study in the literature was examined, no statistically significant relationship is found. The findings in our study are also in this direction. $[39,40,44]$

Our study finds that the most common problem resulting from mobbing is the loss of communication between the perpetrator and the victim $(38.2 \%$ of the cases). Some studies suggest that insulting one's professional skills, excessive task assignment, personal attacks are used as mobbing methods in general.[45,46]

Our study finds that the most common response to mobbing is to share it with friends. This response is most common in the 36-45 age group, university graduates, midwife-nurse group and PHC employees group. Other studies also reveal that the most common response to mobbing is to share it with friends and family.[39,40,47-49]

A study on nurses finds that those who are exposed to mobbing tend to have passive, and those who perpetrate mobbing tend to have aggressive personalities.[33] Our study finds that the period of mobbing in the midwifenurse group is mostly longer than 18 months, while this period shortens to 611 months in the case of doctors. Another study conducted on nurses shows that the people involved in the act of intimidation are insecure, jealous, suspicious and generally in a managerial position, and their behavior occur systematically and continuously between three weeks and three years. Against this, victims of mobbing may not want to reveal their situation too much.[34]

One of the most important steps in preventing mobbing is to take timely measures in organizations and to prevent the problem from harming the organization and employees. Tendencies of mobbing in the workplace and the factors affecting these trends should be determined; clear job descriptions should be made, duties and responsibilities of employees should be determined, the importance of communication should be emphasized and a physical environment where employees can communicate face to face should be created.[25]

Emotional harassment and aggression in the workplace can result in costly problems such as disease, low morale, decreased productivity, high labor turnover, intensive work stress and low job performance. In this context, educating employees about emotional assault within their working environment is proposed as an important solution for them to protect themselves when they are subjected to harassment.

\section{References}

1. Duffy M, Yamada DC. Workplace Bullying and Mobbing in the United States. Second ed., California-Colorado: ABCCLIO, LLC, 2018.

2. Memis M, Durmus S, Cirak K, Ornek M, Kaya M, Yavuz E et al. Violence research of health workers. First Ed., Ankara: Health-Sen Publications -20, December 2013

3. Tumer E.O. Psychological Abuse at Workplaces (Mobbing) Information Guide. The Ministry of Labor and Social Security General Directorate of Labor. Second Ed., Ankara: May 2014.

4. Pilinger J. Violence and harassment against women and men in the world of work : trade union perspectives and action.
International Labour Office, Bureau for Workers' Activities (ACTRAV) Geneva: ILO, 2017

5. Einarsen, S. The Nature and Causes of Bullying At Work. IJM 1999; 20:16-27.

6. Einarsen S, Raknes B.I. Harrasment at Work and the Victimization of Men. Violence Vict 1997;12:247-263.

7. Bayrak KS. Mobbing as a Psycho Violence Spiral in Business Life and Causes. 14th National Management and Organization Congress (25-27 May 2006, Erzurum). The Congress Book 2006, p 434, Erzurum.

8. Tutar H. Psychological Violence in the Workplace. Third ed., Ankara: Platin Publications, 2004.

9. Pelit E, Kılıç I. The Relationship between Mobbing and Organizational Commitment: An Application in City and Public Hotels. J Business Stud 2012; 4/2:122-140

10. Karahan A, Yılmaz H. Mobbing Ve Örgütsel Bağlılık İlişkisine Yönelik Bir Çalışma. J Yaşar University 2014; 9(33):5692-5715

11. Yildırım D, Yıldırım A. Psychological Violence Behaviors of Health Academies and Their Effects. Turkish J Med Sciences 2010;30(2):559-570.

12. Murray JS. Workplace Bullying In Nursing: A Problem That Can't Be Ignored. Medsurg Nurs. 2009;18(5):273-276.

13. Cobanoğlu S. Mobbing- Emotional Attack at Work and Methods of Struggle. First ed., İstanbul: Timaş Psychology Series; 2005.

14. Simons S.R, Mawn B. Bullying In The Workplace--A Qualitative Study Of Newly Licensed Registered Nurses. AAOHN Journal 2010;58(7):305-1.

15. Bag B. Violence Views in Nursing. First ed., Istanbul: Active Publishing, 2004

16. Devanport N, Distler SR, Pursell EG. Mobbing, Emotional Abuse In The American Workplace. OC. Onertoy (Cev.), Istanbul: System Publishing, 2003.

17. Tetik S. Mobbing Concept: Importance for Individuals and Organizations. KMU J Soc and Eco Research 2010;12(18):81-89.

18. Cavalcanti AL, Belo EDR, Marcolino EC, Fernandes A, Cavalcanti YW, de Carvalho DF et al. Occupational Violence against Brazilian Nurses. Iran J Public Health. 2018 Nov;47(11):1636-1643.

19. Ozen CS. Psychological Violence in the Workplace: A Study on Hospital Workers. Work and Society 2008; 4:10733.

20. Yavuz H. Factors Affecting Perception of Mobbing in Employees: SDU A Research On The Faculty Of Medicine. Unpublished Master Thesis, Isparta, Suleyman Demirel University Institute of Social Sciences, 2007.

21. Minton S. J. Minton P. The Application of Certain Phenomenological/Existential Perspectives in Understanding the Bully-Victim Cycle. Existential Analysis J Soc Existential Analysis 2004;15(2):230-242.

22. Chappell D, Di Martino V. Violence at Work. International Labour Organization, Third Edition. Geneva: 2006. 
23. Kirel C. Supporting and Risk Mitigation Recommendations for Mobbing Management in Organizations. Anadolu U J Soc Sci2007; 7(2):317-334.

24. Aydin S, Sahin N, Uzun D. Assessment of Psychological Violence Problems in Organizations in Terms of Hospitality Enterprises. Cukurova U. J Soc Sci 2007;16(2):61-74.

25. Cusack, S. Workplace Bullying: Icebergs in Sight, Soundings Needed. The Lancet. 2000:356(9248):2118.

26. Tanoglu SC. Evaluation of Mobbing in Businesses and Application in a Higher Education Institution. Unpublished Master Thesis, Konya, Selcuk U. Institute of Nat Sci, 2006.

27. Tinaz P. Psychological Abuse at Work (Mobbing). Istanbul: Beta Published, 2006

28. Tutar H, Akbolat M. Mobbing perceptions of health professionals in terms of manager gender. Selcuk U. J Institute of Soc Sci. 2012; 28:19-29.

29. KarcioGlu F, Akbas S. Psychological violence and job satisfaction in the workplace. Atatürk U. J Eco and Adm Sci 2010; 24:139-161.

30. Carıkcı IH, Yavuz H. Mobbing (psychological violence) in employees: A study on health sector workers. SDU J Soc Sci Institute 2009; 2:47-62.

31. Kingma M. Workplace Violence in the Health Sector: A Problem of Epidemic Proportion. Int Nurs Rev 2001;48:129130.

32. Atan, S.U., Donme, S. Workplace violence against nurses. J For Med, 2011;25(1):71-80.

33. Efe SY, Ayaz S. Mobbing Against Nurses İn The Workplace In Turkey. Int Nurs Rev 2010;57(3):328-34

34. Khorsid L, Akın E. Colleague Violence in Nursing. Hospital Management. 2006; (July-Aug-Sep):14-18.

35. Delbel J.C. De-Escalating Workplace Aggression. Nurs Manag 2003; 34:30-34

36. West L.J. The Effect Of An Intervention On The Risk Of Eruptive Violence In The Emergency Department (Master of Science in Nursing), New Haven, Connecticut: Southern Connecticut State University. 2003

37. Hutchinson $M$, Wilkes L, Jackson D, Vickers $M H$. Integrating Individual, Work Group And Organizational
Factors: Testing A Multidimensional Model Of Bullying In The Nursing Workplace. Nurs manag2010;18(2):173

38. Camerino D, Estryn-Behar M, Conway PM, van Der Heijden BI, Hasselhorn HM. Work-Related Factors And Violence Among Nursing Staff In The European NEXT Study: A Longitudinal Cohort Study. Int J Nurs Study 2008;45(1):35-50

39. Ozturk H, Y1lmaz F, Hindistan S. Mobbing Scale for Nurses and Mobbing for Nurses. Hosp Manag 2007;11 (1-2):63-69

40. Dilman T. Determining Emotional Harassment Exposure of Nurses Working in Private Hospitals. Unpublished Master Thesis, Istanbul, Marmara U. Inst. Health Sci, 2007.

41. Davenport N, Schwartz, RD., Eliot GP. Mobbing, Emotional Abuse at Work. Onertoy OC (Cev). Istanbul: System publish, 2003.

42. Bahceci GN, Sagkal T. Investigation of Mobbing Exposure of Nurses Working in Odemis. Maltepe U. J Nurs Sci Art, . 2011; 4(1): 53-62

43. Isık E. A Study on the Relationship between Mobbing and Business Stress in Businesses. Unpublished Master Thesis, Istanbul, Yıldiz Tec U. Ins Soc Sci, 2007.

44. Yıldırım D, Yıldırım A, Timucin A. Mobbing behaviors encountered by nurse teaching staff. Nurs Ethics. 2007;14:447-463.

45. Herath P, Forrest L, McRae I, Parker R. Patient initiated aggression - prevalence and impact for general practice staff. Aust Fam Physician. 2011 Jun;40(6):415-418.

46. Forte M, Przygodzki-Lionet N, Masclet G. From acute victimization at chronic victimization: socio-cognitive approach of differential tolerance threshold. Encephale. 2006 May-Jun;32(3 Pt 1):356-368

47. Kutlu F. The Effect of Mobbing Burnout in the Workplace. Unpublished Master Thesis, Izmir, DOU Soc Sci Inst, 2006.

48. Quine L. Workplace Bullying in Nurses, Journal of Health Psychology, 2001; 6:73-684.

49. Palaz S, Ozkan S, Sarı N, Goze F, Sahin N, Akkurt O. A Research on Psychological Abuse (mobbing) Behaviors at Work; Bandırma Example. "Work, Power" J Indust Rela and Hum Res, 2008; 10(4): 41-58
This work is licensed under Creative Commons Attribution 4.0 License

To Submit Your Article Click Here: Submit Manuscript

DOI: $10.31579 / 2692-9392 / 098$
Ready to submit your research? Choose Auctores and benefit from:

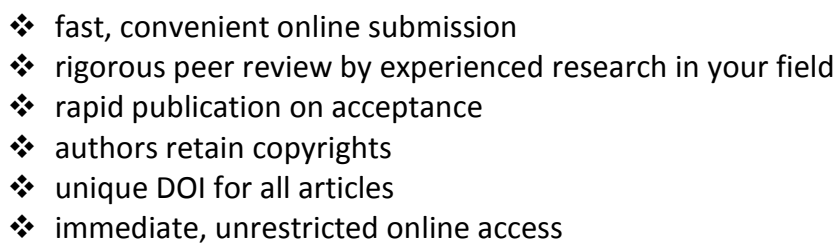

At Auctores, research is always in progress.

Learn more www.auctoresonline.org/journals/archives-of-medical-casereports-and-case-study 